\title{
SPATIAL PLANNING AND DEVELOPMENT IN TOURIST DESTINATIONS: A SURVEY IN A GREEK SPA TOWN
}

\author{
M. PAPAGEORGIOU \& E. BERIATOS \\ Department of Spatial Planning and Regional Development, University of Thessaly, \\ School of Engineering, Volos, Greece.
}

\begin{abstract}
Thermalism - now known as spa tourism - is an age-old activity in Greece, with a long and rich tradition. Through the millennia, Greece has not only managed to maintain the activity of thermalism intact, but has developed it even further, particularly in more recent times (especially since the beginning of the 19th century). Until the middle of the 20th century, Greece invested in quite a high number of spa facilities at various hot springs located throughout the country. Both domestic and foreign visitors were offered a very satisfactory level of spa services - mainly of a therapeutic nature - for a long period of time in the recent past. However, as perceptions concerning thermalism began to change at the end of the 20th century, new, more 'modern' facilities, exclusively dedicated to offering luxury services for health and well-being began to 'pop up' in the same areas, next to the 'classic' type of therapeutic spa facilities. It is certain that however much contemporary trends may force spa tourism to swing toward providing increasingly less therapeutic services, the relegation or supersession of the 'classic' type of facilities and services in the end will not constitute a solution, especially for local communities and the development of those areas.

The present article is the result of extensive field research (the completion of questionnaires) conducted by the authors in the spa town of Kamena Vourla (the second-most important spa town in Greece). It is within the framework outlined above that the article attempts to sketch the various characteristics/profiles of visitors to 'modern' and 'classic' style facilities. The ultimate aim of this research is to suggest that the new type of facilities and their 'tourists' do not constitute a one-way street for the local development of hot springs areas; rather, on the contrary, they may indeed pose a trap if not broadened and suitably combined with the 'classic' type of therapeutic facilities already in place. Finally, based on the conclusions drawn from the research conducted, the article attempts to determine a suitable form of organization that may prove advantageous to spa tourism destinations. It is hoped that this type of organization might help these areas experience viable economic, social, environmental and other development, as viewed within the context of contemporary perceptions and trends. Keywords: classic and modern spa tourists, spa tourism, spa towns, spatial planning and development.
\end{abstract}

\section{INTRODUCTION: THERMALISM IN TRANSITION IN GREECE}

Greece is a country with a significant number of hot springs (approximately 500 according to the National Mineral and Geological Institute-IGME [1-3]). Consequently, thermalism - and the resultant hot springs (spa) tourism - has constituted a very popular activity in the country since antiquity. Specifically, Greece is considered to be the birthplace of thermalism and is the area where the first buildings with spa facilities were constructed. The Asclepieia (5th century BC) were buildings systematically and exclusively built next to hot springs and consisted of temples for the worship of gods and were intended for therapeutic treatments $[4,5]$.

In modern times, the Greek state did not begin to rekindle spa tourism activity until the early 19th century, owing to the Ottoman occupation that had immediately preceded the foundation of the modern Greek state and had lasted centuries. However, the substantial development of spa tourism did not arrive until the beginning of the 20th century [6]. From that point spa tourism grew rapidly, as it constituted the prevailing form of tourism found in the country at the time. Undoubtedly, the Greek state also contributed determinatively to this, by applying extensive and structured development and modernization programs for spa destinations at regular time intervals. Specifically, within this framework, a group of areas with hot springs was suitably prepared to welcome contemporary 
and esthetically well-designed spa facilities and hotels, in the aim of developing spa tourism according to the European standards of the day $[6,7]$.

As a result, for many years - from the 1950s through the 1970s - Greece succeeded in offering spa tourism of a high quality and standard. It achieved this by making available facilities oriented mainly toward the provision of therapeutic treatments; in doing so, it was able to attract a large number of tourists from both within the country and abroad $[8,9]$. However, this prosperity was not to last long. In the 1980s, spa tourism in Greece entered a period of recession and decline [10], mainly because of its inability to adjust to the new trends found in the tourism market, which suggested that spa services and facilities had to emphasize wellness rather than therapy.

This situation finally began to change, but not without a relative delay, around the beginning of the new millennium. In 2000, a small number of modern and luxurious spa facilities, offering 'modern' wellness spa services and treatments, were launched in the Greek tourism market; these were set up next to some of the older, 'classic'-style facilities which continued operating but without updating neither their infrastructure nor their services.

Generally speaking, it could be maintained that this trend, which began at the start of the $21 \mathrm{st}$ century, continues to this day. Specifically, given the fact that the tourism market now dictates that wellness - instead of therapy - constitute the dominant aspect or element of spa tourism. Greek spa destinations have become orientated mainly toward providing 'modern' and luxurious facilities and services, i.e. luxury wellness thermalism. This has come at the expense of the modernization of the more 'classic'-style facilities, which have traditionally provided therapeutic thermalism; consequently, these are continually being pushed aside.

It is within this framework that the present paper aims at defining the form of local and tourist development appropriate for spa destinations, through an examination of the advantages and disadvantages of this new dimension, which the tourism industry has enforced upon spa tourism. To this end, the authors conducted thorough research in Kamena Vourla, a well-known spa town in Greece. Specifically, the research project employed special questionnaires, which were completed by tourists at both types of spa facilities ('modern' and 'classic'), in order to define - and eventually to compare the features and profiles of 'modern' and 'classic' spa tourists. Finally, the ultimate aim of this article is to present the most suitable avenues for spatial planning, which might contribute to the viable spatial and economic development of these areas. This will be attempted through the determination of the type of development that befits the spa destinations found in the country.

\section{METHODOLOGY OF THE SURVEY: THE CASE OF KAMENA VOURLA}

The survey was conducted in Kamena Vourla, the second most important spa town in Greece, which attracts $10 \%$ of the total spa tourist flow in the country [10].

Kamena Vourla is a coastal town, located $175 \mathrm{~km}$ from Athens, and has a population of approximately 3000 people. Up to the 1920s, the area where this well-known Greek spa town is located today was uninhabited and completely unknown despite its richness in hot springs. It was only in 1938 that Kamena Vourla began to be transformed into a promising spa destination, owing to a public and private partnership that resulted in a huge investment project. This saw the construction of a spa facilities building (Asclepius Hydrotherapy Centre) of the highest standard of the day, and also three hotels in the vicinity to accommodate visitors [11].

The continuous growth of spa tourism in Kamena Vourla led to the construction of a second spa building (Hippocrates Hydrotherapy Centre) in 1975, erected next to the first building. Finally, in 2000, the spa town saw the addition of a third building (Galini Wellness Spa), located next to the other two. This newest edifice, which included modern and luxurious facilities, was designed to offer wellness spa treatments (wellness thermalism). 
Today, however, only the Hippocrates and the Galini continue to be in operation, as a result of the supplanting of the therapeutic nature of spa tourism. This means that spa facilities in Kamena Vourla are limited to two choices: one building that offers 'classic' spa facilities and services (providing exclusively therapeutic treatments); and a second with 'modern' spa facilities and services (offering exclusively luxurious wellness treatments).

Taking this fact into consideration, the survey was carried out in these two spa buildings, using a sample of 250 people who completed the special questionnaires drawn up by the authors. Of these, 160 questionnaires were filled in by visitors to the 'classic' spa facility (i.e. the Hippocrates Hydrotherapy Centre, specializing in therapeutic thermalism) and 90 questionnaires were completed by tourists visiting the 'modern' facility (i.e. the Galini wellness spa, which aims at providing wellness thermalism and services). It should be noted that the sample did not contain an equal number of questionnaires completed by visitors to the two kinds of facilities because, in general, 'classic' spa tourists in Greece today significantly outnumber 'modern' spa tourists.

The duration of the survey and the period during which it was conducted also differed between the two facilities. Owing to the limited operating season of the Hippocrates Hydrotherapy Centre (open from early summer through early autumn), the 160 questionnaires related to 'classic' spa tourists were filled in during the summer of 2007. The Galini Wellness Spa operates year-round, and the 90 questionnaires collected from 'modern' spa tourists were completed from June 2007 through May 2008.

In order to process the questionnaires, the authors created a digital database (one suitable for the SPSS program) that permitted the production of the appropriate tables (single and double input). For reasons of space, only a part of the tables is produced and a few necessary figures are presented in the present paper, in the aim of creating a clearer image of the results of the survey.

\section{THE RESULTS OF THE SURVEY: 'CLASSIC' VERSUS 'MODERN' SPA TOURISTS}

In the sections that follow, the paper presents the results from both the survey of the 160 'classic' spa tourists (questionnaires filled in at the Hippocrates Hydrotherapy Centre) and of the 90 'modern' spa tourists (questionnaires completed at the modern facilities of Galini Wellness Spa).

\subsection{The profile of 'classic' spa tourists: the survey in 'Hippocrates hydrotherapy centre'}

Beginning with the research results related to the 'classic' spa tourists, of the 160 people who responded to the questionnaire, $56.3 \%$ were female and $43.7 \%$ male. At the same time, it is worth noting that the overwhelming majority of respondents (some $80 \%$ ) were over 65 years of age (Fig. 1), with males contributing more to this percentage than females (Table 1).

As concerns the place of origin of 'classic' spa visitors, almost half $(44.8 \%)$ came from Athens and the nearby prefecture of Attica (likely owing to the proximity of the area of the Greek capital to Kamena Vourla), while a significant percentage - in the order of $25 \%$ - originated from the wider area of Kamena Vourla (the region of Sterea Ellada) (see Fig. 2). It is also worth noting that aside from the spa visitors who named Athens as their place of origin, the majority of the remainder originated from small towns and villages, with only one 'classic' spa visitor residing overseas (specifically, in Germany).

At the same time, as far as the frequency with which people visit the spa town is concerned, the findings produced by the research show that almost half of the respondents $(45.7 \%)$ had visited more than five times, and also that $61.9 \%$ of visitors had never been to any other spa destination besides Kamena Vourla. Specifically, the exact results are that $34.4 \%$ of 'classic' spa tourists had visited 


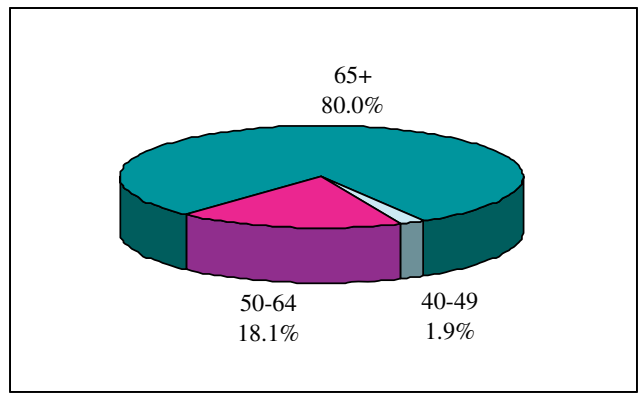

Figure 1: 'Classic' spa tourists' distribution according to age (Kamena Vourla).

Table 1: 'Classic' spa tourists' distribution according to age and sex (Kamena Vourla).

\begin{tabular}{|c|c|c|c|c|c|c|}
\hline \multirow[b]{2}{*}{$\begin{array}{l}\text { Age } \\
\text { (in years) }\end{array}$} & \multicolumn{2}{|c|}{ Male } & \multicolumn{2}{|c|}{ Female } & \multicolumn{2}{|c|}{ Total } \\
\hline & $\begin{array}{l}\text { No. of } \\
\text { persons }\end{array}$ & $\%$ & $\begin{array}{l}\text { No. of } \\
\text { persons }\end{array}$ & $\%$ & $\begin{array}{l}\text { No. of } \\
\text { persons }\end{array}$ & $\%$ \\
\hline $40-49$ & 0 & 0.0 & 3 & 3.3 & 3 & 1.9 \\
\hline $50-64$ & 5 & 7.1 & 24 & 26.7 & 29 & 18.1 \\
\hline$>65$ & 65 & 92.9 & 63 & 70.0 & 128 & 80.0 \\
\hline \multirow{3}{*}{ Total } & 70 & 100.0 & 90 & 100.0 & 160 & 100.0 \\
\hline & & & Chi-squa & & Df & Sig. \\
\hline & & & 13.186 & & 2 & 0.001 \\
\hline
\end{tabular}

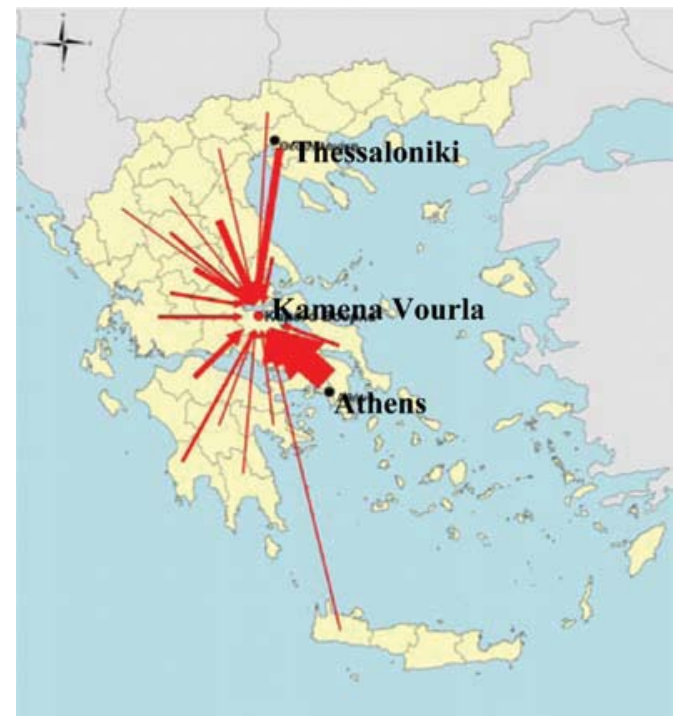

Figure 2: Range of 'classic' spa tourism at Kamena Vourla. 
Kamena Vourla for spa tourism in excess of 10 times, $11.3 \%$ on more than five occasions, $36.2 \%$ between two and five times and, finally, $18.1 \%$ were visiting it for the first time whilst the research was being conducted.

With reference to the duration of their visit, the greatest percentage of 'classic' spa tourists spent from 2 to 3 weeks at the spa town (Fig. 3), that is, the period of time that coincides with one cycle of hydrotherapy. At the same time, as far as the type of accommodation selected for their stay was concerned, this was most frequently either rooms for rent $(46.3 \%)$ or hotels $(40 \%)$, while there was also a significant percentage $(13.7 \%)$ which stayed in private homes in the wider area, owing to the great supply of secondary (holiday) homes available in the vicinity of the spa town.

Concerning their level of income, the 'classic' spa tourists belonged mainly to the lower income brackets. Specifically, the results of the study showed that from the sample of 160 people who filled out the questionnaire, $71.7 \%$ stated that they had an annual income of less than $€ 15,000$ and only $3.1 \%$ stated that their income exceeded $€ 30,000$ annually (Fig. 4).

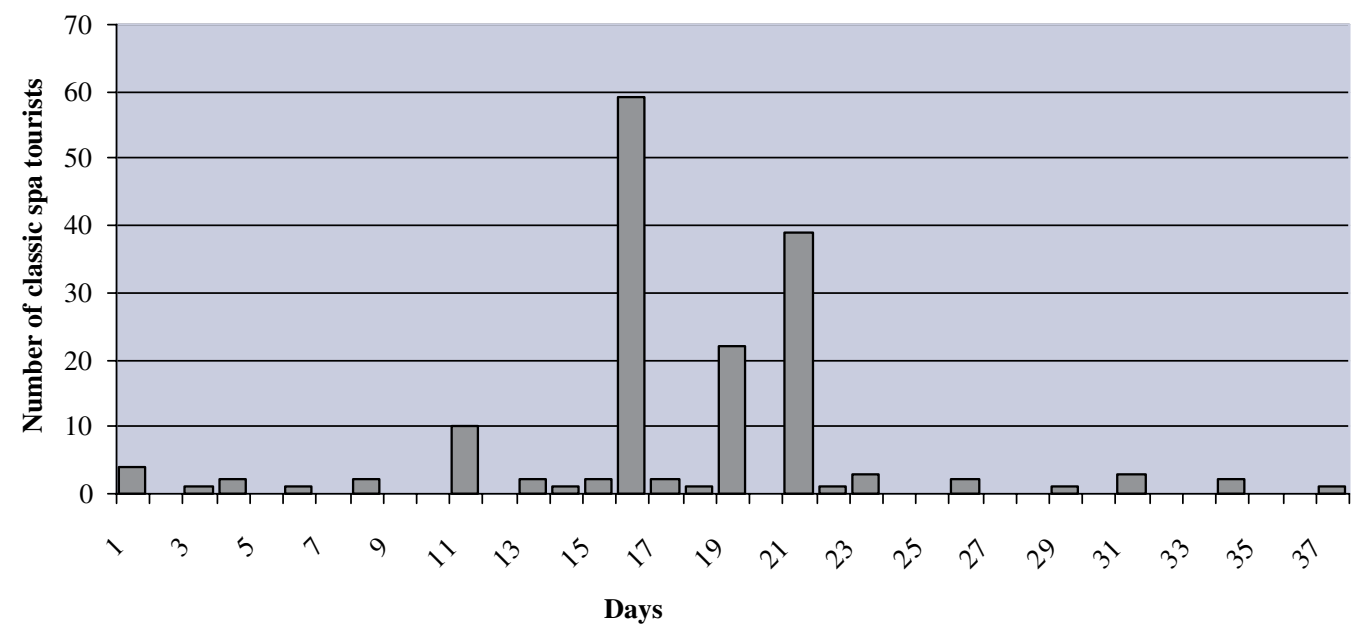

Figure 3: The duration of 'classic' spa tourists stays in Kamena Vourla.

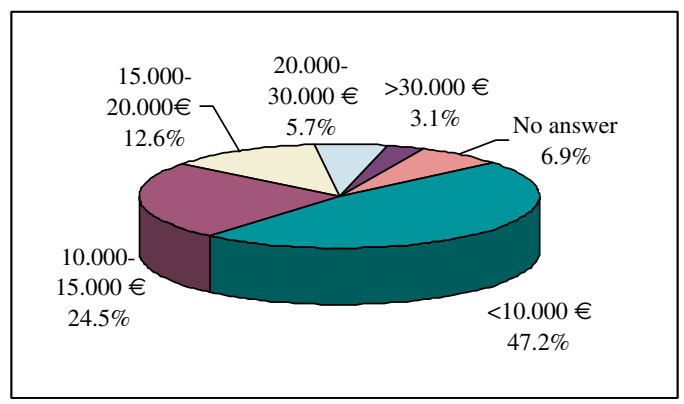

Figure 4: 'Classic' spa tourists' distribution according to annual income (Kamena Vourla). 
Certainly, the fact that therapeutic thermalism attracted lower-income visitors could also be explained in terms of the subsidy provided by the state for this particular activity. As the results of the survey showed, the overwhelming majority (85\%) of 'classic' spa tourists made use of a subsidy provided by either their insurance fund or a certain social program to visit a spa town, in contrast with a small percentage (15\%) that personally covered the cost of their spa tourism activity.

As a consequence of the above, in response to a question which followed concerning whether during their extended stay in the spa town 'classic' spa visitors combined hydrotherapy with some other (including alternative) activities or forms of tourism in the area, a majority of $65.6 \%$ gave a negative response, that is, they stated that they did not take part in any other activities (Tables 2 and 3).

In the other camp, as concerns the 'classic' spa tourists who gave a positive response, that is, those who opted to participate in other activities besides hydrotherapy whilst at the spa town, they represented $34.4 \%$ (55 people) of the total number of those asked. Specifically, the additional activities selected by this particular section of spa tourists were as follows:

\begin{tabular}{lr}
\hline Excursionist tourism & $50.9 \%$ \\
Coastal tourism & $45.5 \%$ \\
Pilgrimage/Religious tourism & $25.5 \%$ \\
Culinary/Food tourism & $14.5 \%$ \\
Cultural tourism & $12.7 \%$ \\
Ecotourism & $5.5 \%$ \\
Hiking/Trekking/Walks & $5.5 \%$ \\
\hline
\end{tabular}

In addition to the results above, which chart the basic characteristics and profiles of 'classic' spa tourists, these visitors were also asked to provide their views on and to rate both the spa town itself and the tourist services and infrastructure. The first issue they were called upon to comment on concerned their level of satisfaction from the offered spa services and infrastructures. The answers provided to this question showed that the majority of 'classic' spa tourists $(80.5 \%)$ were either 'very' or 'quite' satisfied with the offered thermal services, while only $2.3 \%$ were 'not at all' satisfied (Table 4).

In a similar vein, the next issue they were asked to express their views on was related to their level of satisfaction with the natural and built environment of the spa town. The responses to this question reviled once again that the majority of 'classic' spa tourists $(84.9 \%)$ were either 'very' or 'quite' satisfied with the environment of the spa town (Table 4).

Table 2: 'Classic' spa tourists' distribution according to age and willingness to participate in other activities.

\begin{tabular}{|c|c|c|c|c|c|c|}
\hline \multirow[b]{2}{*}{$\begin{array}{l}\text { Age } \\
\text { (in years) }\end{array}$} & \multicolumn{2}{|c|}{ Yes } & \multicolumn{2}{|c|}{ No } & \multicolumn{2}{|c|}{ Total } \\
\hline & $\begin{array}{l}\text { No. of } \\
\text { persons }\end{array}$ & $\%$ & $\begin{array}{c}\text { No. of } \\
\text { persons }\end{array}$ & $\%$ & $\begin{array}{l}\text { No. of } \\
\text { persons }\end{array}$ & $\%$ \\
\hline $40-49$ & 1 & 1.8 & 2 & 1.9 & 3 & 1.9 \\
\hline $50-64$ & 16 & 29.1 & 13 & 12.4 & 29 & 18.1 \\
\hline $65+$ & 38 & 69.1 & 90 & 85.7 & 128 & 80.0 \\
\hline Total & 55 & 100.0 & 105 & 100.0 & 160 & 100.0 \\
\hline
\end{tabular}


Table 3: 'Classic' spa tourists' distribution according to income and willingness to participate in other activities.

\begin{tabular}{|c|c|c|c|c|c|c|}
\hline \multirow[b]{2}{*}{$\begin{array}{l}\text { Annual } \\
\text { income }\end{array}$} & \multicolumn{2}{|c|}{ Yes } & \multicolumn{2}{|c|}{ No } & \multicolumn{2}{|c|}{ Total } \\
\hline & $\begin{array}{l}\text { No. of } \\
\text { persons }\end{array}$ & $\%$ & $\begin{array}{l}\text { No. of } \\
\text { persons }\end{array}$ & $\%$ & $\begin{array}{l}\text { No. of } \\
\text { persons }\end{array}$ & $\%$ \\
\hline$<€ 10,000$ & 14 & 27.5 & 61 & 62.2 & 75 & 50.3 \\
\hline$€ 10-15,000$ & 14 & 27.5 & 25 & 25.5 & 39 & 26.2 \\
\hline$€ 15-20,000$ & 10 & 19.6 & 10 & 10.2 & 20 & 13.4 \\
\hline$€ 20-30,000$ & 8 & 15.7 & 2 & 2.0 & 10 & 6.7 \\
\hline$>€ 30,000$ & 5 & 9.8 & - & - & 5 & 3.4 \\
\hline Total & 51 & 100.0 & 98 & 100.0 & 149 & 100.0 \\
\hline
\end{tabular}

Table 4: Satisfaction of 'classic' spa tourists (\%).

\begin{tabular}{lccccc}
\hline & Not at all & A little & Quite & Much & No answer \\
\hline $\begin{array}{l}\text { Spa services and infrastructure } \\
\text { The environment (natural and }\end{array}$ & 2.3 & 15.1 & 41.0 & 39.5 & 2.1 \\
$\begin{array}{l}\text { built) of the spa town } \\
\begin{array}{l}\text { Accommodation infrastructure } \\
\text { and services }\end{array}\end{array}$ & 2.0 & 11.8 & 43.6 & 41.3 & 0.3 \\
$\begin{array}{l}\text { Entertainment and recreation } \\
\text { services }\end{array}$ & 3.9 & 19.8 & 52.3 & 21.3 & 4.5 \\
\hline
\end{tabular}

Participants were then asked to express their level of satisfaction in relation to accommodation (including lodgings and dining facilities) in the spa town. In their responses to this question, as well, the majority of those asked (73.6\%) replied that they were either 'very' or 'quite' satisfied (Table 4).

The final issue that the 160 'classic' spa tourists were asked to comment on concerned their level of satisfaction with regard to the entertainment and recreation services available in the spa town. Despite the fact that the most common responses to this question as well were 'quite' and 'very' satisfied, those whose reply was 'no answer' amassed an even greater percentage than the former two combined (Table 4). Persons aged 65 and over, as well as people who belonged to the lower income levels, were largely responsible for this last figure, which was generated by the response 'no answer'. They are considered groups unable to afford such activities and/or are generally not interested in them, and thus when asked deemed that the particular question was not relevant to them.

In making a note of these last responses (concerning the level of satisfaction among 'classic' spa tourists) in particular, one ascertains that at first glance 'classic' spa tourists appear to range from 'quite' to 'very' satisfied. However, on the other hand, upon closer examination, what one confirms is that the specific results could even be considered misleading. This is the case because, in essence, senior citizens and those even more advanced in years, whose participation in fact accounts for a great percentage of the sample of 'classic' spa tourists in the spa town, avoid expressing their true views. Thus, if one factors in the belief that the response 'quite' satisfied when expressed by persons of an advanced age contains within it more of a negative rather than a positive judgment, in the end 
it arises that the overall view of the 'classic' spa tourists concerning Kamena Vourla is quite more 'mediocre' than what appears in the statistical results. Despite this and the fact that the level of satisfaction with Kamena Vourla among 'classic' spa tourists is 'mediocre', the responses that were provided concerning the frequency of repeat visits to this particular spa town showed that this lower level of satisfaction was not enough to prevent 'classic' spa tourists from visiting Kamena Vourla, time and again.

\subsection{The profile of 'modern' spa tourists: the survey at the 'Galini wellness spa'}

This presentation of the results of the research study continues with a look at 'modern' spa tourists. A total of 90 persons participated in the study, with women outnumbering men; specifically, $66.7 \%$ of respondents were women, $33.3 \%$ were men. At the same time, as concerns the age of 'modern' spa tourists, relatively young ages come to dominate, the number of those aged over 65 being quite limited (Table 5 and Fig. 5).

In addition, as far as the place of origin of 'modern' spa tourists is concerned, the majority came from either major urban centers around the country - mainly Athens and Thessaloniki - or from abroad (see Fig. 6). Specifically, 78.9\% came from Athens and the prefecture of Attica, $10 \%$ from other countries (Germany, France, Italy, Russia, the Netherlands and Austria), and the remaining $11.1 \%$ were visiting from other areas of Greece (mostly from medium- and large-size provincial cities such as Volos, Larissa, Patras and others).

At the same time, as concerns the frequency with which they visited the spa town for health and wellness thermalism, the results of the research study revealed that in general a significant percentage were regular visitors, and it was also established that an even more noteworthy percentage were visiting the spa town for the first time, most of whom were young under the age of 40. Specifically, the sample of 90 persons showed that $36.7 \%$ were first-time visitors to the 'modern' spa facilities in the town, $30 \%$ had visited these up to five times, $8.9 \%$ had visited from 6 to 10 times, and a significant percentage - in the range of $24.4 \%$ - had visited these facilities on more than 10 occasions.

Table 5: 'Modern' spa tourists' distribution per age and sex (Kamena Vourla).

\begin{tabular}{|c|c|c|c|c|c|c|}
\hline \multirow[b]{2}{*}{$\begin{array}{l}\text { Age } \\
\text { (in years) }\end{array}$} & \multicolumn{2}{|c|}{ Male } & \multicolumn{2}{|c|}{ Female } & \multicolumn{2}{|c|}{ Total } \\
\hline & $\begin{array}{l}\text { No. of } \\
\text { persons }\end{array}$ & $\%$ & $\begin{array}{l}\text { No. of } \\
\text { persons }\end{array}$ & $\%$ & $\begin{array}{c}\text { No. of } \\
\text { persons }\end{array}$ & $\%$ \\
\hline$<40$ & 10 & 33.3 & 23 & 38.3 & 33 & 36.7 \\
\hline 40-49 & 5 & 16.7 & 14 & 23.3 & 19 & 21.1 \\
\hline $50-64$ & 13 & 43.3 & 16 & 26.7 & 29 & 32.2 \\
\hline$>65$ & 2 & 6.7 & 7 & 11.7 & 9 & 10.0 \\
\hline \multirow[t]{3}{*}{ Total } & 30 & 100.0 & 60 & 100.0 & 90 & 100.0 \\
\hline & & & & Chi-Square & Df & Sig. \\
\hline & & & & 2.782 & 3 & 0.427 \\
\hline
\end{tabular}




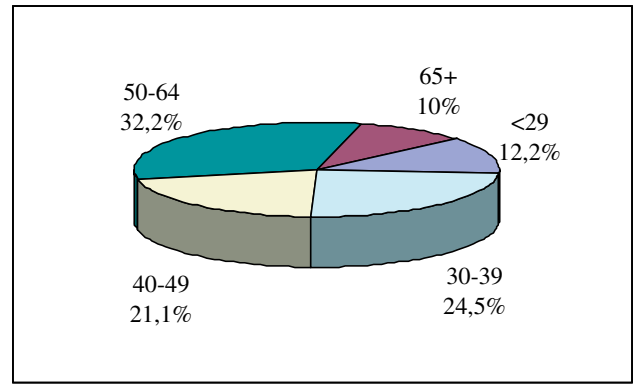

Figure 5: 'Modern' spa tourists' distribution according to age (Kamena Vourla).

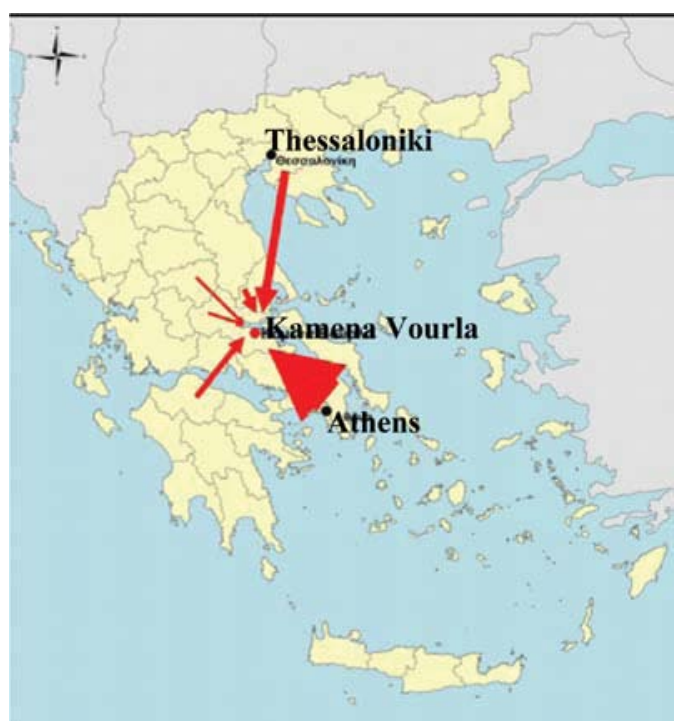

Figure 6: Range of ‘modern' spa tourism at Kamena Vourla.

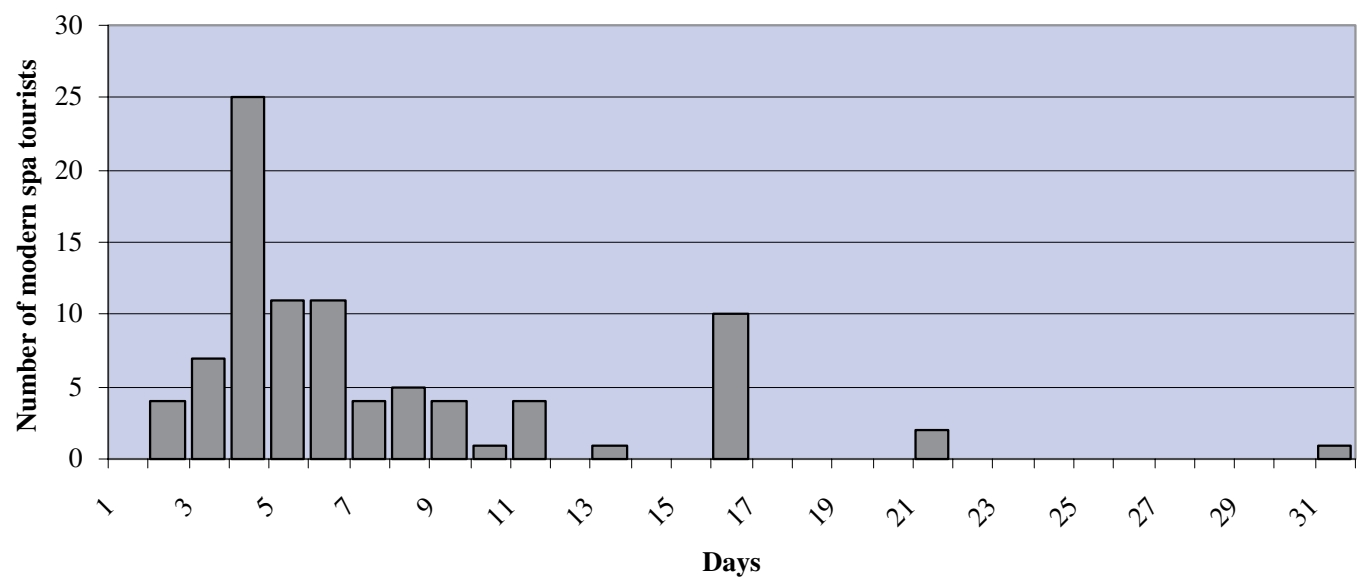

Figure 7: The duration of 'modern' spa tourists stays at Kamena Vourla. 
It is also worth mentioning that of the total of 90 persons who were asked, a percentage of $38.9 \%$ was found to be completely 'faithful' to the facilities of the 'Galini wellness spa', as it had constituted their sole choice until that point for 'modern' health and well-being spa services. By contrast, as concerned the remaining $61.1 \%$ who had visited other areas as well for 'modern' health and well-being spa services, it is typical that over a third (38\%) had visited similar spas in countries abroad (Switzerland, France, Germany, Italy, Austria, Hungary, Russia, etc.), in addition to ones in other parts of Greece.

As concerns the length of their stay, of the sample of 90 'modern' spa tourists, $12.2 \%$ stayed in the spa town for only up to 2 days, $27.7 \%$ stayed only 3 days, $24.4 \%$ from 4 to 5 days, $10 \%$ for 6 to 7 days, and $9.9 \%$ up to 10 days (Fig. 7). At the same time, although there are quite a few visitors who stay at Kamena Vourla for over 10 days, they are usually people who own country homes in the greater area and, consequently, it cannot be argued that the purpose of their extended stay is completely related to a desire on their part to indulge in health and well-being spa services.

As to the type of accommodation 'modern' spa tourists select, the overwhelming majority of those asked had chosen the hotel of the Galini Wellness Spa, that is, the luxury hotel situated in the area where the modern spa facilities are in operation. Specifically, the results of the study showed that $80 \%$ of 'modern' spa tourists in Kamena Vourla had opted to stay at the Galini, a percentage of 3.3\% had chosen another hotel in the spa town, and a significant percentage of $16.7 \%$ were staying in a private residence in the greater area.

With reference to their financial standing, the 'modern' spa tourists were people of a higher income level, with the majority (56.7\%) declaring an income in excess of $€ 20,000$ annually and only $10 \%$ declaring an annual income of less than $€ 10,000$ (Fig. 8).

In addition, as expected, the overwhelming majority of 'modern' spa visitors had themselves assumed the financial burden of the services they were enjoying. Specifically, of the total of 90 people who were taking part in the survey, $91.1 \%$ declared that they were taking care of the cost themselves, while only $6.7 \%$ stated that they were using a subsidy offered by their insurance fund. At the same time, it must be noted that there was also a percentage of $2.2 \%$ whose expenses were being taken care of by a third party.

Further down, the 90 participants in the survey were also asked whether during their (quite restricted) stay they had opted to take part in other activities or forms of tourist activity in the spa town parallel to the spa tourism in which they were participating. According to the results of the questionnaire, $57.7 \%$ gave a positive reply, while an especially significant percentage in the range of $42.2 \%$ provided a negative answer, that is, that they were not taking part in any other activities owing mainly to the limited duration of their stay (which had been aimed almost

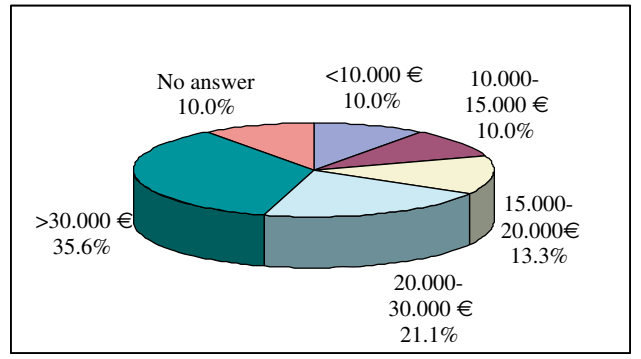

Figure 8: “Modern" spa tourists' distribution according to annual income (Kamena Vourla) 
exclusively at relaxation) but also on account of the lack of alternative activities on offer in the spa town. Specifically, as Tables 6 and 7 also indicate, the greatest percentage of people who had opted not to take part in any other activities in the area was of a younger age and/or relatively wealthy.

By contrast, of the total of 52 persons who had given a positive response, their preferences concerning activities/forms of tourism were as follows:

\begin{tabular}{lr}
\hline Excursionist tourism & $74.5 \%$ \\
Coastal tourism & $33.3 \%$ \\
Cultural tourism & $15.7 \%$ \\
Pilgrimage/Religious tourism & $11.8 \%$ \\
Culinary/Food tourism & $5.9 \%$ \\
Hiking/Trekking/Walks & $2.0 \%$ \\
\hline
\end{tabular}

Besides the above questions which aimed at contributing to a 'mapping' of the basic characteristics of 'modern' spa tourists, respondents were also asked to express their opinion on the quality of services and infrastructure of the spa town. Specifically, with reference to their degree of satisfaction with the offered spa infrastructure and services, the results of the survey showed that $92.2 \%$ were either 'very' or 'quite' satisfied. At the same time, there was also a percentage in the range of $4.5 \%$ that did not answer the question at all (Table 8).

Subsequently, the same visitors were asked to express their level of satisfaction concerning the accommodation-related infrastructure and services offered in the spa town. Once again, in response to the question, the majority appeared from 'quite' to 'very' satisfied, while a percentage of $7.8 \%$ did not give any answer at all to the question (Table 8).

In contrast to this, when asked to comment on their level of satisfaction related to the natural and built environment of the spa town, the majority of respondents replied that they were 'quite' satisfied (Table 8).

The final issue they were asked to express was their degree of satisfaction on concerned entertainment and recreation services. As in the case of 'classic' spa tourists, here as well the percentage of 'modern' spa tourists that did not respond at all to the question amounted to $45.6 \%$ (Table 8). In this

Table 6: 'Modern' spa tourists' distribution according to age and willingness to participate in other activities.

\begin{tabular}{lcccccccc}
\hline & \multicolumn{2}{c}{ Yes } & & \multicolumn{2}{c}{ No } & & \multicolumn{2}{c}{ Total } \\
\cline { 2 - 3 } $\begin{array}{l}\text { Age } \\
\text { in years) }\end{array}$ & $\begin{array}{c}\text { No. of } \\
\text { persons }\end{array}$ & $\%$ & & $\begin{array}{c}\text { No. of } \\
\text { persons }\end{array}$ & $\%$ & & $\begin{array}{c}\text { No. of } \\
\text { persons }\end{array}$ & $\%$ \\
\hline$<40$ & 16 & 30.8 & & 17 & 44.7 & 33 & 36.7 \\
$40-49$ & 10 & 19.2 & & 9 & 23.7 & & 19 & 21.1 \\
$50-64$ & 19 & 36.5 & & 10 & 26.3 & & 29 & 32.2 \\
$>65$ & 7 & 13.5 & & 2 & 5.3 & & 9 & 10.0 \\
Total & 52 & 100.0 & & 38 & 100.0 & & 90 & 100.0 \\
\hline
\end{tabular}


Table 7: 'Modern' spa tourists' distribution according to annual income and willingness to participate in other activities.

\begin{tabular}{|c|c|c|c|c|c|c|}
\hline & \multicolumn{2}{|c|}{ Yes } & \multicolumn{2}{|c|}{ No } & \multicolumn{2}{|c|}{ Total } \\
\hline & $\begin{array}{l}\text { No. of } \\
\text { persons }\end{array}$ & $\%$ & $\begin{array}{l}\text { No. of } \\
\text { persons }\end{array}$ & $\%$ & $\begin{array}{l}\text { No. of } \\
\text { persons }\end{array}$ & $\%$ \\
\hline$<€ 10,000$ & 5 & 10.9 & 4 & 11.4 & 9 & 11.1 \\
\hline$€ 10-15,000$ & 6 & 13.0 & 3 & 8.6 & 9 & 11.1 \\
\hline$€ 15-20,000$ & 7 & 15.2 & 5 & 14.3 & 12 & 14.8 \\
\hline$€ 20-30,000$ & 9 & 19.6 & 10 & 28.6 & 19 & 23.5 \\
\hline$>€ 30,000$ & 19 & 41.3 & 13 & 37.1 & 32 & 39.5 \\
\hline Total & 46 & 100.0 & 35 & 100.0 & 81 & 100.0 \\
\hline
\end{tabular}

Table 8: Satisfaction of 'modern' spa tourists (\%).

\begin{tabular}{lccccc}
\hline & Not at all & A little & Quite & Much & No answer \\
\hline $\begin{array}{l}\text { Spa services and infrastructure } \\
\begin{array}{l}\text { The environment (natural and } \\
\text { built) of the spa town }\end{array}\end{array}$ & 1.1 & 2.2 & 31.1 & 61.1 & 4.5 \\
$\begin{array}{l}\text { Accommodation infrastructure } \\
\text { and services }\end{array}$ & 2.4 & 21.1 & 53.3 & 22.2 & 0.0 \\
$\begin{array}{l}\text { Entertainment and recreation } \\
\text { services }\end{array}$ & 2.2 & 10.0 & 36.7 & 43.3 & 7.8 \\
\hline
\end{tabular}

instance, however, according to the results of the study, the reasons why 'modern' spa tourists deemed that the particular question did not concern them was the limited duration of their stay, in combination with the fact that their visit to the spa town exclusively served purposes of rest and not entertainment.

Of course, at this point it must be clarified that especially in the case of the questions related to spa services and the accommodation services offered, the fact that the majority of 'modern' spa tourists replied that they were from 'quite' to 'very' satisfied should not mislead us. Most of them (some $80 \%$ ) stayed at the spa town's luxurious complex (the Galini), enjoying the equally luxurious wellness spa services that it offered. As a consequence, these answers under no circumstance should be considered as applicable to the spa town as a whole; in fact, the two other questions (concerning satisfaction with the natural and built environment and entertainment/recreation services), about which the 'modern' spa tourists showed a lesser degree of satisfaction, indicate how they felt about the spa town in general. Despite all of this, one must say that independent of the view that 'modern' spa tourists may hold regarding the spa town, the fact that they are satisfied, be it only with the luxurious spa and hotel infrastructures, make them return to Kamena Vourla quite frequently. 


\section{COMMENTS AND CONCLUSIONS: IN SEARCH OF SUSTAINABLE LOCAL DEVELOPMENT IN SPA TOWNS}

In taking a quick look at the above results, one would say it is clear that the category of spa tourists in which the spa tourism areas of Greece must 'invest' is the 'modern' one, as both their age- and finance-related features hold an advantage over those of 'classic' spa tourists. However, this evident finding is not necessarily correct; a more careful look at the sum of the results produced by the research project reveals that the conclusions that arise are entirely different.

Specifically, if one were to attempt a more incisive and combinative interpretation of the results, regarding the impact of spa tourists - of both categories - to the local development, the following conclusions of the research project would truly be useful in determining the form of planning appropriate for spa tourism areas:

- Although 'modern' spa tourists are mainly of a younger age and relatively well-off financially, their contact with the local community and economy ranges from minimal to non-existent, because of their limited stay in the spa town (which in the main is at the luxurious Galini complex). However, it appears that the local community itself bears a substantial share of the responsibility for this development, since, as the research findings show, the existing planning of the spa town (economic, spatial, etc.) does not offer appropriate and/or adequate alternative services and infrastructure, ones able to attract and draw 'modern' spa tourists away from the luxury of the facilities to be found where they are staying, in order that the whole town benefit financially.

- In the other camp - as concerns 'classic' spa tourists - even though it is a fact that they do become more involved in the local community and economy (they choose to stay in rented rooms, visit for long periods of 2 or 3 weeks, etc.), they ultimately offer very little to the local development of the area, owing to their limited financial ability and their age range.

Thus, a basic conclusion that arises from the above is that, in the end, the contribution made to the local economy by these two diametrically opposed categories of spa tourists found at Kamena Vourla (but generally speaking also found in many other spa towns in Greece) ranges, for a variety of reasons, from minimal to non-existent. This means, in principle, that the economic planning and the categories of tourists that the spa town of Kamena Vourla has 'opted' to invest in ultimately has not benefited local development. In addition, the spatial planning program that has been put into effect does not appear to have created the suitable conditions to induce the 'diffusion' of economic development to the entire spectrum of activity in the spa town; this is evident, in general, in the fact that neither 'classic' nor 'modern' spa tourists are attracted to or find any interest in much alternative entertainment/recreation activities in the area.

Consequently, it becomes immediately evident, in accordance with the above, that if Greek spa tourism is to find a way out of the impasse and halt the declining course it has been placed on, it will have to be built on a modern and integrated spatial and economic planning base. Undoubtedly, in order for this planning to be viable, it will have to be aimed more at a 'diffusion' of economic benefits and development to the whole of the spa town, rather than at a unilateral economic reinforcement of individual, isolated businesses, as the Galini complex is in this case.

Thus, in setting out as the main goal the lifting of these problems and more importantly the viable economic and spatial development of an area of spa destination/spa town, the planning to be implemented must be based on five main components [12]:

- The provision of reliable spa tourism services and infrastructures, orientated toward the supply of services aimed at both therapeutic thermalism and health and well-being, and to which all economic classes - and not only the affluent - would have access (especially with regard to health and well-being spa services). 
- The enlargement of the target group that this particular form of tourism is geared toward, in order that it become possible to also attract an intermediate category of spa tourists. These tourists, most of whom would belong to the middle class, would not find themselves 'trapped' within the luxurious spa complex during their stay in the spa town, but instead would actively contribute to the local economy and to the development of both the immediate and greater area.

- The upgrading of the operations of the spa town and mainly of the infrastructures and leisure services (museums, libraries, cinemas, art halls, etc.) which would permit necessary alternative activities to be offered to visitors/spa tourists and enable, as a consequence, contact and a reciprocality of benefits so that local development take place.

- The upgrading of the urban planning of the entire spa town (new pedestrian precincts, the creation of bicycle lanes and paths, the provision of sufficient parking spaces and areas, etc.) aimed at enhancing the attractiveness of the town and also so that it acquire a strong identity as a tourist destination and specifically as a spa town.

- The upgrading of the hinterland, mainly through the 'exploitation' and 'elevation' of its natural and cultural 'resources', in the aim of strengthening the attractiveness and competitiveness of the greater area as a tourist destination.

\section{EPILOGUE}

It is a fact that, in Greece, spa tourism is going through a transition period. Its main characteristic is the supersession of the old type of spa facilities, and the supremacy of modern and luxurious health and well-being facilities, which, in the main, attract affluent spa visitors. Certainly, however much the emergence of facilities of this type may be desirable (with their contemporary and luxurious health and wellness spa services), the truth is that a greater presence of such facilities would not necessarily provide the solution for the desirable blooming of spa tourism, or for viable local development.

For this reason, the aim of Greece - as of every country that presents a similar picture of spa tourism - must be the provision of facilities and services directed toward a more broadened range of spa tourists, from all economic and social strata. In other words, the economic planning related to the activity of thermalism must be widened in order to encompass intermediate categories of facilities as well, and so as not to remain rigidly fixed within the two extreme categories that co-exist at the moment (classic hydrotherapy facilities/modern and luxurious health and well-being thermalism facilities). Besides this, however, and in order that a much-desired viable and fully fledged local development be achieved, whatever planning decided upon must not stop there. On the contrary, it must be extended and accompanied by suitable spatial planning, which whatever the case must ensure not only adequate infrastructure and leisure services, but also a spatial intervention aimed at the upgrading of the attractiveness of both the immediate area (the spa town) and the wider environment (the hinterland).

\section{REFERENCES}

[1] Gioni-Stavropoulou, G., Census of Mineral Hot Springs of Greece I: Aegean Sea, Hydrologic and Hydro-Geological Research No. 39, Institute of Geological and Mineral Research: Athens (in Greek), 1983.

[2] Orfanos, G., Census of Mineral Hot Springs of Greece II: Peloponnese, Hydrologic and Hydro-Geological Research No. 39, Institute of Geological and Mineral Research: Athens (in Greek), 1985. 
[3] Sfetsos, K.S., Census of Mineral Hot Springs of Greece III: Continental Greece, Hydrologic and Hydro-Geological Researches No. 39, Institute of Geological and Mineral Research: Athens (in Greek), 1988.

[4] Greek Association of Hot Springs Municipalities - Greek Thermal Agency, Hot Springs and Spa Towns: Greek Thermalism, G.A.H.S.M. - G.T.A.: Thessaloniki (in Greek), 2006.

[5] Skarpia-Hoipel, X., Hydrotherapy and Leisure: Historical Evolution of Hot Baths, University Studio Press: Thessaloniki (in Greek), 1996.

[6] Charitakis, C., Hot Springs and Spa Towns in Greece, Medical Encyclopedia: "Anexartitos" Newspaper Publications: Athens (in Greek), 1935.

[7] Lekkas, N., The 752 Mineral Springs of Greece, Institute of Geological and Mineral Research: Athens (in Greek), 1938.

[8] GNTO - Greek National Tourism Organization, Spa Towns and Hot Springs, GNTO: Athens (in Greek), 1966.

[9] GNTO - Greek National Tourism Organization, Spa Towns and Hot Springs: 1951-19521953, GNTO: Athens (in Greek), 1954.

[10] Spathi, S., The Development of Spa and Health Tourism in Greece, KEPE: Athens (in Greek), 2000.

[11] Skouras, C., The Spa Town of Kamena Vourla, Thessaloniki, 1957.

[12] Beriatos, E. \& Papageorgiou, M., Towards sustainable spa tourism activities in Greece. Sustainable Development and Planning IV, eds. C.A. Brebbia, M. Neophytou, E. Beriatos, I. Ioannou \& A.G. Kungolos, WIT Press: Southampton, Boston, pp. 773-782, 2009. 